\title{
Relationship Between the Bone Formation Rate and Functional Status in Symptomatic Knee Osteoarthritis
}

\author{
Semptomatik Diz Osteoartritinde Kemik Yapım Hızı ile Fonksiyonel Durum Arasındaki İlişki
}

\author{
Demet TEKDÖŞ DEMİRCİOĞLU, ${ }^{1}$ Nurdan PAKER, ${ }^{2}$ Derya SOY BUĞDAYCI ${ }^{2}$ \\ ${ }^{1}$ Department of Physical Medicine and Rehabilitation, Memorial Hizmet Hospital, İstanbul, Turkey; \\ ${ }^{2}$ Department of Physical Medicine and Rehabilitation, İstanbul Physical Medicine and Rehabilitation, \\ Training and Research Hospital, İstanbul, Turkey
}

Objectives: This study aims to investigate the relationship between serum levels of bone-specific alkaline phosphatase and functional status in patients with symptomatic knee osteoarthritis (OA).

Patients and methods: Seventy patients (57 females, 13 males; mean age $57.5 \pm 9.3$ years; range 48 to 67 years) diagnosed with knee OA based on the American College of Rheumatology (ACR) criteria and 30 age- and gender-matched healthy controls (mean age $56.4 \pm 7.5$ years) were enrolled in the study. Patients were evaluated using clinical, laboratory and radiographic methods. Bone-specific alkaline phosphatase and 24-hour urinary calcium and phosphorus levels were tested to assess bone metabolism. The Lequesne index was used for the severity of disease and the Western Ontario and McMaster Universities Osteoarthritis Index (WOMAC) was used for the functional status.

Results: The mean bone-specific alkaline phosphatase value was $13.69 \pm 4.76 \mathrm{mg} / \mathrm{dl}$ in the patient group. No statistically significant difference was found between the patient group and the control group in terms of bone-specific alkaline phosphatase values $(p=0.584)$. The bone formation rate was high in $28.5 \%$ of the patients. A significantly positive correlation was found between the bone-specific alkaline phosphatase and the WOMAC stiffness scores $(p=0.07, r=0.340)$. No significant correlation was found between the bone-specific alkaline phosphatase and the pain, physical function, and the total scores of the WOMAC and Lequesne index $(p=0.590, r=0.090$, $p=0.489, r=0.107, p=0.413, r=0.139, p=0.285, r=0.70$ respectively).

Conclusion: In this study, an increase was shown in the bone formation rate in approximately $1 / 4$ of the patients with symptomatic knee osteoarthritis. A significant positive correlation was found between bone formation rate and knee stiffness. However, no relationship was observed between the bone formation rate and pain, physical function, when they were compared with severity of the disease.

Key words: Knee; osteoarthritis; osteogenesis.
Amaç: Bu çalışmada semptomatik diz osteoartriti (OA) olan hastalarda kemiğe özgü serum alkalen fosfataz düzeyi ile fonksiyonel durum arasındaki ilişki araştırıldı.

Hastalar ve yöntemler: Bu çalışmaya Amerikan Romatoloji Birliği (ACR) kriterlerine göre diz OA tanısı konulan 70 hasta (57 kadın, 13 erkek; ort. yaş $57.5 \pm 9.3 \mathrm{yıl}$; dağılım $48-67 \mathrm{yıl}$ ) ile yaş ve cinsiyet açısından uyumlu 30 sağlıklı kontrol (ort. yaş $56.4 \pm 7.5$ yıl) alındı. Hastalar klinik, laboratuvar ve radyografik yöntemlerle değerlendirildi. Kemik metabolizmasının değerlendirilmesi için kemiğe özgü alkalen fosfataz ve 24 saatlik üriner kalsiyum ve fosfor düzeyleri test edildi. Hastalık şiddeti için Lequesne indeksi, fonksiyonel durum için Western Ontario and McMaster Üniversitesi Osteoartrit İndeksi (WOMAC) kullanıldı.

Bulgular: Kemiğe özgü alkalen fosfataz değeri, hasta grubunda ortalama $13.69 \pm 4.76 \mathrm{mg} / \mathrm{dl}$ idi. Kemiğe özgü alkalen fosfataz değerleri açısından kontrol grubu ile hasta grubu arasında istatistiksel olarak anlamlı bir fark bulunmadı $(p=0.584)$. Hastaların \%28.5'inde kemik yapım hızı yüksek idi. Kemiğe özgü alkalen fosfataz ile WOMAC tutukluk skoru arasında ise anlamlı pozitif korelasyon bulundu $(p=0.07, r=0.340)$. Kemiğe özgü alkalen fosfataz ile ağrı, fiziksel fonksiyon, WOMAC total skoru ve Lequesne indeksi arasında anlamlı korelasyon bulunmadı (sırasıyla, $p=0.590, r=0.090, p=0.489$, $r=0.107, p=0.413, r=0.139, p=0.285 r=0.70)$.

Sonuç: Bu çalışmada semptomatik diz osteoartriti olan hastaların yaklaşık 1/4'ünde kemik yapım hızında artış olduğu gösterilmiştir. Kemik yapım hızı ile dizdeki tutukluk arasında anlamlı bir pozitif ilişki bulunmuştur. Ancak hastalık şiddeti ile karşılaştırıldığında kemik yapım hızı, ağrı ve fiziksel fonksiyon arasında herhangi bir ilişki gözlemlenmemiştir.

Anahtar sözcükler: Diz; osteoartrit; osteogenez. 
Osteoarthritis (OA) is a common pathology that involves the synovial joints. Alterations of bone and synovial tissue metabolism may occur along with cartilage destruction in OA.$^{[1,2]}$ During its progression, the structure of the cartilage deteriorates in cases of increased bone in the subchondral bone, thinning of the trabecular structure, and additional destruction. ${ }^{[3]}$

In recent years, it has been found that different biochemical markers were indicative of bone turnover in animal models and humans. These markers can be measured in the serum or urine, providing information about the formation and destruction of the bone. Studies show that these biochemical markers are sensitive to alterations in the bone turnover rate. ${ }^{[4]}$

Concentrations of proactive and active metalloproteinase and alkaline phosphatase (ALP) and subchondral bone turnover were shown to increase in subchondral bone specimens obtained from patients with a total hip prosthesis for osteoporosis or OA. ${ }^{[5]}$ Previous studies in patients with knee, hip, spine, and hand OA revealed contradictory results for bone formation and resorption. ${ }^{[5-13]}$ Although most of them demonstrated that biochemical markers increased in $\mathrm{OA},{ }^{[5-11]}$ some reported that there was no alteration or gradual decline in bone turnover ${ }^{[12,13]}$ Osteoarthritis affects all biomechanical dynamics of the joint, resulting in functional failure. The functional assessment aims to measure the abilities and limitations of a person in managing daily life, occupational interests, social relations, and other behaviors. ${ }^{[14]}$

The objective of the present study was to investigate the correlation between bone-specific alkaline phosphatase (BALP) and functional status in patients with symptomatic knee OA.

\section{PATIENTS AND METHODS}

The cross-sectionally designed study included a total of 70 patients (57 females, 13 males; mean age $57.5 \pm 9.3$ years; range 48 to 67 years), who were admitted to the Istanbul Physical Medicine and Rehabilitation Training Hospital Clinic with complaints of knee pain and were diagnosed with knee OA according to the American College of Rheumatology (ACR) criteria between February 1 and September 30, 2008. The control group consisted of 30 healthy individuals, matched according to age and gender (mean age 56.4 \pm 7.5 years), with no complaints of knee pain.
Those patients exhibiting secondary OA, osteoporosis, any disease or medications which affect bone metabolism were excluded.

The evaluations included routine blood biochemistry and complete blood count along with erythrocyte sedimentation rate (ESR), C-reactive protein (CRP), and rheumatoid factor levels. A urinalysis was also performed, and standard anteroposterior and lateral radiographs of the knee were obtained while patients were standing.

In all patients, BALP, 24-hour urinary calcium $(\mathrm{Ca})$, and phosphorous (P) levels were measured to assess bone metabolism. Fasting blood samples were drawn before 09:00 AM. Bone mineral density (BMD) was measured using dual-emission X-ray absorptiometry (DXA, previously DEXA) (Lunar DPX Pro, Madison, Wisconsin) at the lumbar spine and proximal femur.

Bone-specific alkaline phosphatase concentrations of patients were measured by in-vitro quantitative determination of ALP in serum or plasma (Orthophosphoric-monoester phosphohydrolase, alkaline optimum, EC 3.1.3.1, Thermo Electron Corporation, Pittsburgh, USA).

Radiological assessment was made according to the Kellgren-Lawrence classification. Severity of disease and functional status were measured using the Western Ontario and McMaster Universities (WOMAC) OA and Lequesne Indices.

The WOMAC OA Index, a disease-specific measuring tool, is a common scale used for patients with knee or hip osteoarthritis. It consists of three subscales: stiffness, pain, and physical function. Higher WOMAC scores indicate increased pain and stiffness along with poor physical functions. ${ }^{[15]}$

The Lequesne Index is another disease-specific measuring tool which addresses pain, walking distance, and activities of daily life in patients with osteoarthritis. Higher scores indicate higher functional limitation. ${ }^{[16]}$

Statistical Package for Social Sciences (SPSS Inc., Chicago, Illinois, USA) 15.0 software package for Windows was used for statistical analysis during the evaluation of data. A score of $\mathrm{p}<0.05$ was considered statistically significant.

Compairments were evaluated by Student's t-test while correlations were assessed by the Spearman correlation test. 
The study was carried out according to the principles outlined in the Declaration of Helsinki, and approval was obtained from the hospital's ethics committee.

\section{RESULTS}

The mean body mass index (BMI) was $30.5 \pm 5.0$ and $29.0 \pm 5.0 \mathrm{~kg} / \mathrm{m}^{2}$ respectively in the patient and control groups, and no differences were found between age and BMI in the two groups $(p=0.680)$. The mean duration of disease was $6.22 \pm 5.67$ years. According to the Kellgren-Lawrence radiological grading system, the mean radiological grade was $2.83 \pm 0.52$. Table 1 summarizes the individual and total scores for the WOMAC subscales of pain, stiffness, and physical function as well as the mean Lequesne Index score.

The Ca, P, ALP and BALP levels of the patient and control groups are shown in table 2 . No significant differences were found in the blood values between the two groups $(\mathrm{p}=0.810, \mathrm{p}=0.453, \mathrm{p}=0.346 \mathrm{p}=0.254)$.

In the patient group, ESR was $24.7 \pm 11.3 \mathrm{~mm} / \mathrm{st}$, CRP was $0.5 \pm 0.4 \mathrm{mg} / \mathrm{dl}$, 24-hour urinary $\mathrm{Ca}$ was $145.6 \pm 111.9 \mathrm{mg}$, and $P$ was $584.9 \pm 222.4 \mathrm{mg}$. The 24-hour urinary $\mathrm{Ca}$ and $P$ levels were within normal limits.

Table 3 summarizes the relationship between the WOMAC OA and Lequesne Indices and the Ca, P, ALP, and BALP levels.

Table 1. WOMAC and Lequesne scores of patients with knee osteoarthritis

\begin{tabular}{lccc}
\hline & $\begin{array}{c}\text { Median } \\
(\mathrm{n}=70)\end{array}$ & $\begin{array}{c}\text { Minimum } \\
(\mathrm{n}=70)\end{array}$ & $\begin{array}{c}\text { Maximum } \\
(\mathrm{n}=70)\end{array}$ \\
\hline WOMAC pain & 6 & 0 & 16 \\
WOMAC stiffness & 0 & 0 & 6 \\
WOMAC function & 19 & 0 & 53 \\
WOMAC total & 45 & 4 & 75 \\
Lequesne total & 8 & 0 & 21 \\
$\begin{array}{l}\text { WOMAC: Western Ontario and McMaster Universities Index; Descriptive } \\
\text { statistics were used for analysis. }\end{array}$
\end{tabular}

Table 2. Laboratory parameters

\begin{tabular}{lccc}
\hline & $\begin{array}{c}\text { Patients } \\
(\mathrm{n}=70)\end{array}$ & $\begin{array}{c}\text { Control } \\
(\mathrm{n}=30)\end{array}$ & $p$ \\
\hline $\mathrm{Ca}(\mathrm{mg} / \mathrm{dL})$ & $9.14 \pm 0.527$ & $8.91 \pm 0.621$ & 0.810 \\
$\mathrm{P}(\mathrm{mg} / \mathrm{dL})$ & $3.22 \pm 0.580$ & $3.04 \pm 0.423$ & 0.453 \\
$\mathrm{ALP}(\mathrm{mg} / \mathrm{dL})$ & $76.92 \pm 22.90$ & $79.24 \pm 21.42$ & 0.346 \\
$\mathrm{BALP}(\mathrm{mg} / \mathrm{dL})$ & $13.69 \pm 4.760$ & $14.31 \pm 5.55$ & 0.254 \\
\hline $\begin{array}{l}\text { Ca: Calcium; } \\
\text { specific alkaline phosphorous; ALP: Alkaline phosphatase; BALP: Bone- }\end{array}$ \\
\hline
\end{tabular}

A significant positive correlation was found between BALP and the stiffness subscale scores of WOMAC $(\mathrm{p}=0.02, \mathrm{r}=0.392)$. There was no significant correlation between BALP levels and the subscale scores and total score of WOMAC for pain and physical functioning $(\mathrm{p}=0.458, \mathrm{r}=0.099, \mathrm{p}=0.265, \mathrm{r}=0.147, \mathrm{p}=0.229, \mathrm{r}=0.159)$

No significant relationship was found between BALP levels and mean Lequesne Index values $(p=0.415$, $\mathrm{r}=0.108$ ).

A statistically significant positive correlation was found between BALP levels when compared with ESR and CRP values $(\mathrm{p}=0.00, \mathrm{r}=0.380)$.

The BMD values of the femoral neck and lumbar region were $0.928 \pm 0.105 \mathrm{~g} / \mathrm{cm}^{2}$ and $1.122 \pm 0.244 \mathrm{~g} / \mathrm{cm}^{2}$ respectively in the patient group. The $\mathrm{T}$ scores of the femoral neck and lumbar region were $0.396 \pm 0.846$ and $0.002 \pm 1.162$ respectively. Among female patients, 46 were postmenopausal, and 11 were premenopausal. The mean duration of menopause was $8.99 \pm 7.44$ years. No correlation was found between the duration of menopause and BALP $(\mathrm{p}=0.796, \mathrm{r}=0040)$.

\section{DISCUSSION}

The present study showed a significant correlation between BALP levels and WOMAC stiffness scores. However, no significant relationship was observed between WOMAC pain and physical functioning when compared with disease severity scores and BALP levels.

Table 3. Relationship between WOMAC OA index, Lequesne index, and $\mathrm{Ca}, \mathrm{P}, \mathrm{ALP}$ and BALP levels in the patient group

\begin{tabular}{|c|c|c|c|c|}
\hline & $\mathrm{Ca}$ & $\mathrm{P}$ & ALP & BALP \\
\hline \multicolumn{5}{|c|}{ WOMAC pain } \\
\hline r value & -0.006 & 0.088 & -0.045 & 0.099 \\
\hline $\mathrm{p}$ value & 0.965 & 0.513 & 0.738 & 0.458 \\
\hline \multicolumn{5}{|c|}{ WOMAC stiffness } \\
\hline r value & -0.068 & 0.074 & 0.173 & 0.392 \\
\hline $\mathrm{p}$ value & 0.613 & 0.582 & 0.194 & $0.002^{*}$ \\
\hline \multicolumn{5}{|c|}{ WOMAC function } \\
\hline r value & -0.074 & -0.120 & 0.108 & 0.147 \\
\hline $\mathrm{p}$ value & 0.583 & 0.369 & 0.419 & 0.265 \\
\hline \multicolumn{5}{|c|}{ WOMAC total } \\
\hline r value & -0.069 & 0.100 & 0.087 & 0.159 \\
\hline $\mathrm{p}$ value & 0.605 & 0.455 & 0.515 & 0.229 \\
\hline \multicolumn{5}{|c|}{ Lequesne total } \\
\hline r value & -0.162 & 0.00 & 0.076 & 0.108 \\
\hline $\mathrm{p}$ value & 0.225 & 1.00 & 0.571 & 0.415 \\
\hline \multicolumn{5}{|c|}{$\begin{array}{l}\text { WOMAC: Western Ontario and McMaster Universities Index; Ca: Calcium; } \\
\text { P: Phosphorus; ALP: Alkaline phosphatase; BALP: Bone-specific alkaline } \\
\text { phosphatase; Correlation is significant at the } 0.05 \text { level; Spearman correlation } \\
\text { test was used for statistical analysis. }\end{array}$} \\
\hline
\end{tabular}


Although there have been many previous studies on functional status in patients with knee OA, there is no study evaluating the relationship between bone turnover and functional status.

The present study showed that $28.5 \%$ of patients with symptomatic knee OA had higher BALP levels, an indicator of bone formation. However, the bone formation rate was not statistically different in the patient group when compared with the control group.

Studies on patients with OA have shown different results regarding bone turnover. Some studies have shown an increase in the markers of bone turnover, including patients with involvement at different locations such as the hip, spine, and hand. ${ }^{[5-12]}$

A study by Hunter et al. ${ }^{[17]}$ reported that among markers of bone turnover, BALP osteocalcin, and CTx and NTx (N- and C-terminal collagen cross-links) levels were within normal limits whereas urinary deoxypyridinoline levels were increased. Another study on patients with advanced OA (28 involving the knee and 32 involving the hip joint) showed higher serum BALP and urinary deoxypyridinoline levels. ${ }^{[18]}$

However, some other studies suggest that markers of bone turnover are not increased. ${ }^{[19,20]}$ The level of bone markers may not necessarily imply increased bone turnover as restructuring of the bone in question is local. It is already known that biochemical markers indicating bone turnover may differ with the timing of sampling, osteoporosis, menopausal state, age, and several diseases. ${ }^{[21]}$ Bone-specific alkaline phosphatase is a highly consistent marker for daily alterations. Furthermore, the present study showed no significant relationship between the menopausal state, gender, and bone formation. Each of the patients underwent osteoporosis evaluation by DXA with results within the normal range.

The present study showed a significant relationship between BALP levels and CRP and ESR values. It indicates that the bone formation rate may also increase in patients with acute inflammation. In a study by Kim et al. ${ }^{[22]}$ conducted with high sensitivity CRP and biochemical markers of bone turnover in pre- and postmenopausal healthy women, BALP levels had a tendency to increase along with elevated high sensitivity CRP levels.

In conclusion, the present study showed a significant positive correlation between the bone formation rate and knee stiffness in women with symptomatic knee OA. Longitudinal studies, including bone formation and resorption indicators in patients with knee $\mathrm{OA}$, may provide further beneficial data about the use of these markers.

\section{Declaration of conflicting interests}

The authors declared no conflicts of interest with respect to the authorship and/or publication of this article.

\section{Funding}

The authors received no financial support for the research and/or authorship of this article.

\section{REFERENCES}

1. Garnero P, Piperno M, Gineyts E, Christgau S, Delmas PD, Vignon E. Cross sectional evaluation of biochemical markers of bone, cartilage, and synovial tissue metabolism in patients with knee osteoarthritis: relations with disease activity and joint damage. Ann Rheum Dis 2001;60:619-26.

2. Bettica P, Cline G, Hart DJ, Meyer J, Spector TD. Evidence for increased bone resorption in patients with progressive knee osteoarthritis: longitudinal results from the Chingford study. Arthritis Rheum 2002;46:3178-84.

3. Karsdal MA, Leeming DJ, Dam EB, Henriksen K, Alexandersen P, Pastoureau P, et al. Should subchondral bone turnover be targeted when treating osteoarthritis? Osteoarthritis Cartilage 2008;16:638-46.

4. Calvo MS, Eyre DR, Gundberg CM. Molecular basis and clinical application of biological markers of bone turnover. Endocr Rev 1996;17:333-68.

5. Takahashi M, Kushida K, Inoue T. Receiver operating characteristic analysis of urinary pyridinium cross-links in arthritis. Br J Rheumatol 1995;34:792-3.

6. Otterness IG, Swindell AC, Zimmerer RO, Poole AR, Ionescu M, Weiner E. An analysis of 14 molecular markers for monitoring osteoarthritis: segregation of the markers into clusters and distinguishing osteoarthritis at baseline. Osteoarthritis Cartilage 2000;8:180-5.

7. Naitou K, Kushida K, Takahashi M, Ohishi T, Inoue $\mathrm{T}$. Bone mineral density and bone turnover in patients with knee osteoarthritis compared with generalized osteoarthritis. Calcif Tissue Int 2000;66:325-9.

8. Stewart A, Black A, Robins SP, Reid DM. Bone density and bone turnover in patients with osteoarthritis and osteoporosis. J Rheumatol 1999;26:622-6.

9. MacDonald AG, McHenry P, Robins SP, Reid DM. Relationship of urinary pyridinium crosslinks to disease extent and activity in osteoarthritis. Br J Rheumatol 1994;33:16-9.

10. Seibel MJ, Duncan A, Robins SP. Urinary hydroxypyridinium crosslinks provide indices of cartilage and bone involvement in arthritic diseases. J Rheumatol 1989;16:964-70.

11. Astbury C, Bird HA, McLaren AM, Robins SP. Urinary excretion of pyridinium crosslinks of collagen correlated with joint damage in arthritis. Br J Rheumatol 1994;33:11-5. 
12. Takahashi M, Suzuki M, Naitou K, Miyamoto S, Kushida $\mathrm{K}$. Comparison of free and peptide-bound pyridinoline cross-links excretion in rheumatoid arthritis and osteoarthritis. Rheumatology (Oxford) 1999;38:133-8.

13. Sowers M, Lachance L, Jamadar D, Hochberg MC, Hollis $\mathrm{B}$, Crutchfield $\mathrm{M}$, et al. The associations of bone mineral density and bone turnover markers with osteoarthritis of the hand and knee in pre- and perimenopausal women. Arthritis Rheum 1999;42:483-9.

14. Kucukdeveci A, Koc N. Functional assesment in Osteoarthritis. Turkiye Klinikleri J PMR Special Topics 2008;1:40-7.

15. Bellamy N, Buchanan WW, Goldsmith $\mathrm{CH}$, Campbell J, Stitt LW. Validation study of WOMAC: a health status instrument for measuring clinically important patient relevant outcomes to antirheumatic drug therapy in patients with osteoarthritis of the hip or knee. J Rheumatol 1988;15:1833-40.

16. Lequesne MG, Samson M. Indices of severity in osteoarthritis for weight bearing joints. J Rheumatol Suppl 1991;27:16-8.

17. Hunter DJ, Hart D, Snieder H, Bettica P, Swaminathan R, Spector TD. Evidence of altered bone turnover, vitamin D and calcium regulation with knee osteoarthritis in female twins. Rheumatology (Oxford) 2003;42:1311-6.

18. Hulejová H, Spacek P, Klézl Z, Trc T, Adam M. Changes in the articular compartment in advanced osteoarthritis. Acta Chir Orthop Traumatol Cech 2003;70:248-52. [Abstract]

19. Sharif M, George E, Dieppe PA. Correlation between synovial fluid markers of cartilage and bone turnover and scintigraphic scan abnormalities in osteoarthritis of the knee. Arthritis Rheum 1995;38:78-81.

20. Kim HJ, Lee HM, Kim HS, Park JO, Moon ES, Park $\mathrm{H}$, et al. Bone metabolism in postmenopausal women with lumbar spinal stenosis: analysis of bone mineral density and bone turnover markers. Spine (Phila Pa 1976) 2008;33:2435-9.

21. Campion GV, Delmas PD, Dieppe PA. Serum and synovial fluid osteocalcin (bone gla protein) levels in joint disease. Br J Rheumatol 1989;28:393-8.

22. Kim BJ, Yu YM, Kim EN, Chung YE, Koh JM, Kim GS. Relationship between serum hsCRP concentration and biochemical bone turnover markers in healthy preand postmenopausal women. Clin Endocrinol (Oxf) 2007;67:152-8. 